\title{
Regulation of the secretion of Rhizopus oligosporus extracellular carboxyl proteinase
}

\author{
Peter C. FARLeY* and LiLik IKasari \\ Fakultas Biologi, Universitas Kristen Satya Wacana, Salatiga 50711, Indonesia
}

(Received 27 May 1992; revised 24 July 1992; accepted 25 August 1992)

\begin{abstract}
Secretion of the extracellular Rhizopus carboxyl proteinase (EC 3.4.23.6) by Rhizopus oligosporus is repressed in the presence of low-molecular-mass sources of nitrogen, sulphur and carbon. Proteinase is secreted when the medium is deficient in any one of these three nutrients. In the case of nitrogen metabolite repression, control is at the level of transcription. Induction of proteinase secretion by exogenous protein does not occur in any of the media examined.
\end{abstract}

\section{Introduction}

In Indonesia, the filamentous fungus Rhizopus microsporus var. oligosporus (in short: $R$. oligosporus) is of economic importance. It is used in a solid-substrate fermentation to produce tempe from soya beans. While other Rhizopus species can be used to produce tempe, a better quality product is obtained with $R$. oligosporus. During the tempe fermentation growth of $R$. oligosporus mycelium occurs without sporulation. The mycelium, as well as binding the soya beans into a solid cake, invades the intracellular lamellar material of the beans and hydrolyses it by the activity of its extracellular enzymes (Nout \& Rombouts, 1990). These include lipase, polygalacturonase, endocellulase, xylanase, arabinanase, phytase and the aspartic proteinase, Rhizopus carboxyl proteinase (EC 3.4.23.6). Secretion of this proteinase appears to be a critical determinant in the production of good quality tempe (Wang \& Hesseltine, 1965; Lim et al., 1987). Furthermore, Wang et al. (1974) reported consistently higher yields of the proteinase during solidsubstrate fermentations compared to submerged culture. However, the regulation of proteinase secretion was not examined.

Regulation of proteinase synthesis and secretion has been studied in a number of other fungi and normally involves either induction or repression/derepression or a combination of both. In Aspergillus nidulans (North, 1982) nitrogen, carbon or sulphur limitation is sufficient for extracellular proteinase secretion, whereas in Neurospora crassa (North, 1982) and Mucor miehei (Lasure,

* Author for correspondence. Tel. 6229881362 ; fax 6229881420.
1980), nitrogen, carbon or sulphur limitation is necessary but not sufficient and proteinase secretion must be induced by exogenous protein. The major regulatory mechanism in the basidiomycetes Agaricus bisporus, Coprinus cinereus and Volvariella volvacea appears to be induction by exogenous protein. In these fungi, in contrast to $N$. crassa, repression by nitrogen, sulphur or carbon does not over-ride induction (Kalisz et al., 1987). The mycorrhizal fungus Hymenoscyphus ericae is exceptional in that proteinase secretion is neither repressed by ammonium or other nitrogen sources nor dependent on induction by exogenous protein (Leake \& Read, 1990).

At the molecular level some of the regulatory genes have been identified: $n m r-1$ and nit-2 are the major regulatory genes of the nitrogen circuit in $N$. crassa (Fu \& Marzluf, $1990 b$ ). The equivalent gene in $A$. nidulans, are- $A$, has been shown to control proteinase gene expression (Arst, 1982). The major regulatory genes of the sulphur circuit in $N$. crassa are scon- 1 , scon-2 and cys-3 (Jarai \& Marzluf, 1991). The NIT2 protein and the CYS3 protein bind in a sequence-specific manner upstream of the structural genes they regulate, promoting transcription of these genes. Furthermore, the NIT2 protein can substitute for AREA in A. nidulans (Davis \& Hynes, 1987).

The present work examines the regulation of proteinase secretion in $R$. oligosporus.

\section{Methods}

Strains. Unless stated otherwise, $R$. oligosporus USDB 0224 from the Botany Department, National University of Singapore was used. For some experiments $R$. oligosporus R116 obtained from the Pusat Penelitian Pembangunan Gizi, Bogor, Indonesia was also used. 
Media. Liquid minimal medium contained $55 \mathrm{~mm}$-glucose, $50 \mathrm{~mm}$ $\mathrm{NH}_{4} \mathrm{Cl}, 11.2 \mathrm{mM}-\mathrm{KH}_{2} \mathrm{PO}_{4}, 7 \mathrm{mM}-\mathrm{KCl}, 2.1 \mathrm{mM}-\mathrm{MgSO}_{4}$ and traces of ferrous and zinc chlorides. Treatment media for transfer experiments (Cohen, 1973) were obtained by modification of minimal medium as follows: nitrogen-free medium did not contain $\mathrm{NH}_{4} \mathrm{Cl}$, sulphur-free medium contained $\mathrm{MgCl}_{2}$ in place of $\mathrm{MgSO}_{4}$ unless stated otherwise, carbon-free medium did not contain glucose, medium containing protein as sole nitrogen source was nitrogen-free medium containing $0.2 \% \mathrm{BSA}$, medium containing an amino acid as sole nitrogen source was nitrogen-free medium containing either arginine $(20 \mathrm{mM})$ or threonine $(20 \mathrm{mM})$, medium containing protein as sole sulphur source was sulphur-free medium containing BSA $(1 \%, w / v)$, medium containing protein as sole carbon source was carbon-free medium containing BSA $(1 \%, w / v)$. For some experiments, as indicated in the text, the concentrations of selected components of these treatment media were increased five-fold. The stock solution of BSA was $5.6 \%$ $(w / v)$ dialysed against at least five changes of distilled water and sterilized $(0.2 \mu \mathrm{m}$ filter). In experiments to determine the effect of inhibitors of RNA and protein synthesis on the secretion of proteinase, treatment medium also contained one of the following: ethidium bromide $\left(50,100\right.$ or $\left.250 \mu \mathrm{g} \mathrm{ml}^{-1}\right)$, cordycepin $\left(50\right.$ or $\left.300 \mu \mathrm{g} \mathrm{ml}^{-1}\right)$ or puromycin $\left(50\right.$ or $\left.300 \mu \mathrm{g} \mathrm{ml}^{-1}\right)$.

Growth conditions. Exponentially growing mycelium was harvested from submerged cultures incubated with shaking at room temperature for $12-14 \mathrm{~h}$ after inoculation with $10^{7}$ spores per $25 \mathrm{ml}$ (Farley, 1991). At this stage of growth the mycelium had formed clumps, which rapidly settled when the flask was removed from the shaker. Mycelium was filtered on UV-sterilized filter paper, washed with treatment medium $(100 \mathrm{ml})$, transferred to fresh treatment medium $(20 \mathrm{ml})$ and returned to the shaker. The mycelium stuck together as a thin mat. If the flask was not shaken there was no secretion of proteinase even under derepression conditions. After the transfer, cultures contained about $1 \mathrm{mg}$ dry weight of mycelium $\mathrm{ml}^{-1}$. In all experiments the mycelial dry weight was measured at the end of the incubation in treatment medium by filtering on glass fibre filters and drying $\left(80^{\circ} \mathrm{C}\right)$ to constant weight. For those experiments in which proteinase specific activity was calculated at intermediate time points, the mycelial dry weights were calculated from measurements made at the beginning (separate flask) and end of the incubation. In all experiments involving nutrient limitation there was no growth during the incubation in treatment medium. Samples of the culture supernatant were removed at the times indicated and stored at $-20^{\circ} \mathrm{C}$ for enzyme assay. The proteinase was stable under these conditions for at least one week. All results are the average of at least two independent experiments unless indicated otherwise.

Proteinase assay. Proteinase activity was measured at $40^{\circ} \mathrm{C}$ (Wang \& Hesseltine, 1965). Each incubation $(0.15 \mathrm{ml})$ contained $4 \mathrm{mg}$ BSA ml-1, 0.05 $\mathrm{M}$-citrate phosphate buffer, pH 3.3, and enzyme. Trichloroacetic acid $(10 \%, \mathrm{w} / \mathrm{v}, 0.1 \mathrm{ml})$ was added after $45 \mathrm{~min}$ incubation, and following centrifugation the acid-soluble hydrolysis products were determined as tyrosine equivalents using a modified Lowry method as described by Eggstein \& Kreutz (1967) except that the alkaline copper reagent was $0.01 \% \mathrm{CuSO}_{4} .5 \mathrm{H}_{2} \mathrm{O}$ and $2 \%(\mathrm{w} / \mathrm{v})$ $\mathrm{Na}_{2} \mathrm{CO}_{3}$ in $0 \cdot 1 \mathrm{M}-\mathrm{NaOH}$. A blank was prepared in the same way but the trichloroacetic acid was added prior to the enzyme. One unit of proteinase activity (U) was defined as the release of $1 \mathrm{nmol}$ of tyrosine equivalents per $45 \mathrm{~min}$. Under the conditions described release of tyrosine equivalents was linear for at least $60 \mathrm{~min}$ and the rate of hydrolysis was proportional to added enzyme up to $3 \mathrm{nmol}$ tyrosine equivalents $\min ^{-1}$. For some experiments in which there was little proteinase in the culture supernatant the incubation was extended to $3 \mathrm{~h} 45 \mathrm{~min}$. Enzyme assays were performed at least in duplicate except when culture supernatants were sampled every hour. The enzyme activity measured under these conditions is Rhizopus carboxyl proteinase as determined by the response to the inhibitor pepstatin.

\section{Results and Discussion}

\section{Nitrogen-metabolite repression}

When $R$. oligosporus USDB 0224 mycelium growing in minimal medium was transferred to nitrogen-free medium, secretion of the extracellular carboxyl proteinase began within two hours of transfer (Fig. 1) and continued at a constant rate $\left(360 \mathrm{U} \mathrm{mg}^{-1} \mathrm{~h}^{-1}\right)$ for the next $4 \mathrm{~h}$ (Figs 1 and 2). A similar lag phase was observed with both $A$. nidulans (Cohen, 1973) and $N$. crassa (Cohen et al., 1975). Cohen (1973) reported enzyme activity in arbitrary units so that comparison of the rate of proteinase secretion by $R$. oligosporus and $A$. nidulans is not possible. The rate of proteinase secretion obtained with $R$. oligosporus was however, similar to that observed with $N$. crassa (Cohen et al., 1975). A low but detectable level of proteinase was found when the mycelium was instead transferred to fresh minimal medium (Fig. 1; max. rate of secretion: $13 \mathrm{U} \mathrm{mg}^{-1} \mathrm{~h}^{-1}$ ). However, after $5 \mathrm{~h}$ incubation, the proteinase specific activity in nitrogen-free medium was at least 40 -fold higher than in minimal medium (Fig. 1). This is lower than the difference (about 200-fold) observed with $A$. nidulans (Cohen, 1973). However, increasing five-fold the concentration of glucose and $\mathrm{MgSO}_{4}$ in the medium increased the level of proteinase almost two-fold higher again (Table 1: Experiment 1). Proteinase secretion is therefore derepressed in nitrogen-free medium but repressed in minimal medium, even in the presence of exogenous protein (Fig. 1). Similar results were obtained with $R$. oligosporus $\mathrm{R} 116$.

Compared with nitrogen-free medium, proteinase secretion began slightly earlier when mycelium was transferred to medium containing protein $(0.2 \%)$ as the sole nitrogen source (Fig. 1). However, the maximum rate of secretion ( $395 \mathrm{U} \mathrm{mg}^{-1} \mathrm{~h}^{-1}$ ) and yield of proteinase were similar. Furthermore, the rate at which proteinase was secreted began to decline some $2 \mathrm{~h}$ earlier than in nitrogen-free medium. In $N$. crassa, induction of proteinase secretion by exogenous protein causes a $20-$ fold increase in the rate of proteinase secretion (Cohen $e t$ al., 1975). There is therefore, no induction of proteinase secretion under these conditions; rather, the amino acids and peptides released by hydrolysis of the protein may be beginning to cause repression at the end of the $5 \mathrm{~h}$ incubation. This idea is supported by the finding that there is little secretion of proteinase in medium containing arginine ( $20 \mathrm{mM})$ as sole nitrogen source and partial repression in medium containing threonine $(20 \mathrm{mM})$ as sole nitrogen source (Table 1 : Experiment 2). Both these 


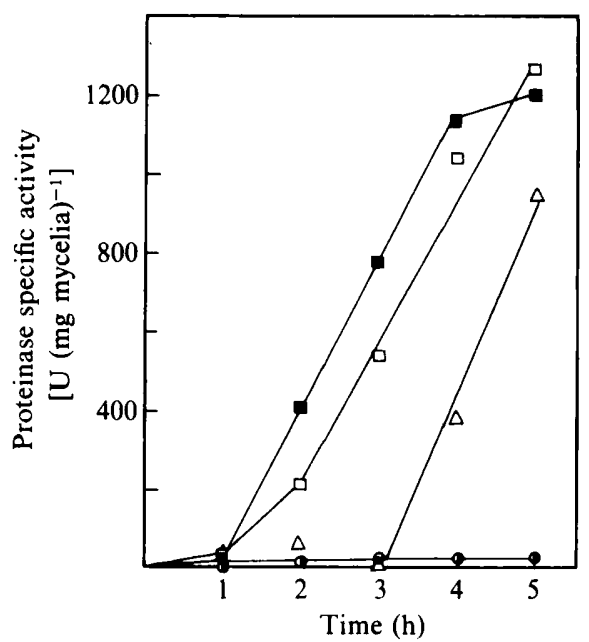

Fig. 1. Specific activity of $R$. oligosporus USDB 0224 extracellular carboxyl proteinase after transfer to treatment media. Each point is the mean of at least two independent experiments. Transfer from minimal medium to: fresh minimal medium $(O)$; fresh minimal medium containing $0.2 \%$ BSA $(\bullet)$; nitrogen-free medium $(\square)$; sulphurfree medium $(\triangle)$; medium containing BSA $(0 \cdot 2 \%)$ as sole nitrogen source ( $\mathbf{\square})$.

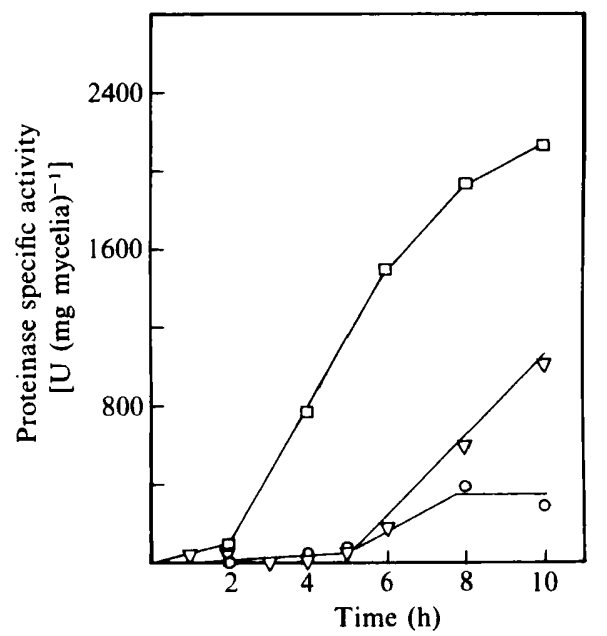

Fig. 2. Specific activity of $R$. oligosporus USDB 0224 extracellular carboxyl proteinase after transfer to treatment media. Each point is the mean of at least two independent experiments. Transfer from minimal medium to: fresh minimal medium $(O)$; nitrogen-free medium $(\square)$; carbon-free medium $(\nabla)$.

amino acids also repress proteinase secretion in $N$. crassa when protein is the sole nitrogen source (Cohen \& Drucker, 1977). In $N$. crassa, induction by exogenous protein requires a protein concentration of at least $0.5 \%$ but even with $1 \%(\mathrm{w} / \mathrm{v})$ protein as sole nitrogen source there is no induction of proteinase secretion in $R$. oligosporus (Table 2).
Table 1. Effect on proteinase secretion of various modifications to the nitrogen-free treatment medium

$R$. oligosporus USDB 0224 mycelium was transferred to nitrogenfree treatment medium or nitrogen-free medium which had been modified as shown. The mycelium was incubated in the treatment medium for $5 \mathrm{~h}$ as described in Methods. Proteinase activity and mycelial dry weight were determined as described in Methods. Results are means of at least duplicate determinations for two independent experiments.

\begin{tabular}{|c|c|c|}
\hline \multirow[b]{2}{*}{ Treatment medium } & \multicolumn{2}{|c|}{ Specific activity } \\
\hline & $\begin{array}{l}\text { [units (mg } \\
\text { mycelia) }{ }^{-1} \text { ] }\end{array}$ & $(\%)$ \\
\hline \multicolumn{3}{|l|}{ Experiment 1} \\
\hline Nitrogen-free medium & 1220 & - \\
\hline Nitrogen-free (275 mM glucose, $\left.10.5 \mathrm{mM}-\mathrm{MgSO}_{4}\right)$ & 2250 & - \\
\hline \multicolumn{3}{|l|}{ Experiment 2} \\
\hline Nitrogen-free medium & 900 & 100 \\
\hline Thr $(20 \mathrm{~mm})$ as sole nitrogen source & 530 & 59 \\
\hline Arg $(20 \mathrm{~mm})$ as sole nitrogen source & 60 & 6 \\
\hline \multicolumn{3}{|l|}{ Experiment 3} \\
\hline Nitrogen-free medium & 1090 & 100 \\
\hline Nitrogen-free, $50 \mu \mathrm{g}$ ethidium bromide $\mathrm{ml}^{-1}$ & 510 & 47 \\
\hline Nitrogen-free, $100 \mu \mathrm{g}$ ethidium bromide $\mathrm{ml}^{-1}$ & 350 & 32 \\
\hline Nitrogen-free, $250 \mu \mathrm{g}$ ethidium bromide $\mathrm{ml}^{-1}$ & 180 & 17 \\
\hline
\end{tabular}

Table 2. Effect of exogenous protein on Rhizopus carboxyl proteinase secretion

$R$. oligosporus USDB 0224 mycelium was transferred to treatment medium as described in Methods except that the concentration of BSA used in all these experiments was $1 \%(\mathrm{w} / \mathrm{v})$ and media which did not contain inorganic sulphur were prepared simply by omitting $\mathrm{MgSO}_{4}$. Following incubation, with shaking at room temperature, proteinase activity and mycelial dry weight were measured as described in Methods. Results are the means of two independent experiments.

\begin{tabular}{lcc}
\hline \hline \multicolumn{1}{c}{ Treatment medium } & $\begin{array}{c}\text { Incubation } \\
\text { time } \\
\text { (h) }\end{array}$ & $\begin{array}{c}\text { Specific activity } \\
\text { [units (mg mycelia) }\end{array}$ \\
\hline Nitrogen-free & 5 & 1130 \\
Protein as sole nitrogen source & 5 & 1100 \\
Sulphur-free & 5 & 1000 \\
Protein as sole sulphur source & 5 & 270 \\
Carbon-free & 10 & 1150 \\
Protein as sole carbon source & 10 & 440 \\
\hline \hline
\end{tabular}

To examine whether or not the secretion of proteinase in nitrogen-free medium required protein and/or RNA synthesis, mycelium was transferred to nitrogen-free medium containing inhibitors of transcription or translation. In one experiment using nitrogen-free medium containing puromycin $\left(300 \mu \mathrm{g} \mathrm{ml}^{-1}\right)$, an inhibitor of translation, the proteinase specific activity after $5 \mathrm{~h}$ incubation at room temperature was only $15 \%$ 
[257 $\mathrm{U}(\mathrm{mg} \text { mycelia })^{-1}$ ] of that for mycelium transferred to nitrogen-free medium. In a similar experiment using cordycepin $\left(300 \mu \mathrm{g} \mathrm{ml}^{-1}\right)$, an inhibitor of RNA synthesis, the proteinase specific activity was only $32 \%$ [556 $\mathrm{U}$ (mg mycelia) ${ }^{-1}$ ] of the control. In experiments using $R$. oligosporus strain $\mathrm{R} 116$ and these inhibitors at a lower concentration $\left(50 \mu \mathrm{g} \mathrm{ml}^{-1}\right)$, inhibition of secretion was observed but to a lesser extent. These experiments indicate that both protein and RNA synthesis are required for proteinase secretion. The importance of RNA synthesis was confirmed by experiments, using another inhibitor of RNA synthesis (Table 1: Experiment 3), in which the extent of inhibition of proteinase secretion was dependent on the ethidium bromide concentration. The difference in the extent of inhibition by cordycepin and ethidium bromide may be caused by differences in the ability of these two compounds to cross the mycelial cell wall, as has been reported for the yeast Candida albicans (Shepherd et al., 1980). If this is so, then these experiments suggest that at least $83 \%$ of the proteinase secreted in nitrogen-free medium was derived from newly transcribed mRNA. Further experiments are required to identify which gene(s) are being transcribed. In $N$. crassa, besides the structural genes for enzymes subject to nitrogen metabolite control, transcription of at least one of the regulatory genes (nit-2) is regulated by nitrogen metabolite repression (Fu \& Marzluf, 1987).

\section{Sulphur-metabolite repression}

Transfer of mycelium to sulphur-free medium also resulted in the secretion of proteinase (Fig. 1). Proteinase secretion began about an hour later than in nitrogen-free medium but the maximum rate of secretion was slightly higher $\left(460 \mathrm{U} \mathrm{mg}^{-1} \mathrm{~h}^{-1}\right)$. There was no significant difference between sulphur-free medium in which the $\mathrm{MgSO}_{4}$ was substituted with $\mathrm{MgCl}_{2}$ and medium in which the $\mathrm{MgSO}_{4}$ was simply omitted. That proteinase activity was not detectable until $3 \mathrm{~h}$ after the transfer may reflect differences in the nitrogen and sulphur pools present in the mycelium at the time of transfer or may be due to differences between the structure of the nitrogen and sulphur control circuits themselves. In $A$. nidulans, the maximum rate of secretion is also slightly higher and the lag phase longer in sulphur-free medium compared to nitrogen-free medium (Cohen, 1973).

In sulphur-free medium, there was no induction of proteinase secretion by exogenous protein (Table 1); rather, the protein, or more likely products of its hydrolysis, caused repression of proteinase secretion.

\section{Carbon-metabolite repression}

Proteinase secretion was derepressed in carbon-free medium (Fig. 2) but secretion of proteinase did not begin until $5 \mathrm{~h}$ after transfer, and the maximum rate of secretion was only $200 \mathrm{U} \mathrm{mg}^{-1} \mathrm{~h}^{-1}$, about half the rate of secretion obtained in nitrogen- or sulphur-free medium. These results are in contrast with what was found in $A$. nidulans (Cohen, 1973) where there is no difference in either the lag phase or the maximum rate of proteinase secretion between nitrogen-free and carbon-free medium.

In fresh minimal medium there was an increase in the level of extracellular proteinase between 5 and $10 \mathrm{~h}$ after transfer (Fig. 2). Even when the concentrations of glucose, $\mathrm{NH}_{4} \mathrm{Cl}$ and $\mathrm{MgSO}_{4}$ were increased 5-fold, the level of extracellular proteinase in fresh minimal medium increased between 6 and $10 \mathrm{~h}$. One possible explanation is that with continued growth, regions of the mycelial mat which no longer have direct contact with the medium, may experience localized limitation of available nitrogen, sulphur or carbon sources, with resultant synthesis and secretion of proteinase, even though the concentration of these nutrients in the medium is still high. In spite of this, the level of proteinase in carbon-free medium $10 \mathrm{~h}$ after transfer was on average 3-fold higher than for fresh minimal medium, indicating that in carbon-free medium there is release from carbon metabolite repression. The $\mathrm{pH}$ of the minimal medium did decrease during the $10 \mathrm{~h}$ incubation but was always within the range at which the proteinase is at least $90 \%$ stable over $16 \mathrm{~h}$ at $28^{\circ} \mathrm{C}$ (Wang \& Hesseltine, 1965).

In media containing $275 \mathrm{~mm}$-glucose, $250 \mathrm{~mm}-\mathrm{NH}_{4} \mathrm{Cl}$ and $10.5 \mathrm{~mm}-\mathrm{MgSO}_{4}$, there was no difference between the levels of proteinase in carbon-free and minimal medium (193 and $185 \mathrm{U} \mathrm{mg}^{-1} \mathrm{~h}^{-1}$, respectively, $10 \mathrm{~h}$ after transfer). The low level of proteinase secretion in carbon-free medium and in carbon-free medium containing $250 \mathrm{~mm}-\mathrm{NH}_{4} \mathrm{Cl}$ and $10.5 \mathrm{~mm}-\mathrm{MgSO}_{4}$ was not due to changes in the $\mathrm{pH}$ of the medium. The $\mathrm{pH}$ of the medium was always within the range at which the proteinase is stable. It would appear that, as in $N$. crassa (Cohen et al., 1975), secretion of proteinase under conditions of carbon limitation requires a medium of low ionic strength.

In carbon-free medium there was no induction of proteinase secretion by exogenous protein (Table 2).

While there have been no studies directed at understanding the regulation of proteinase synthesis and secretion in $R$. oligosporus, there have been studies aimed at optimizing Rhizopus carboxyl proteinase production in other varieties of the $R$. microsporus group. Schindler $e t$ al. (1983) stated that proteinase secretion by $R$. microsporus var. rhizopodiformis was subject to repression by inorganic nitrogen and by the products of starch hydrolysis but that protein secretion required exogenous protein as a nitrogen source and inducer. However, they do not appear to have considered the possibility of 


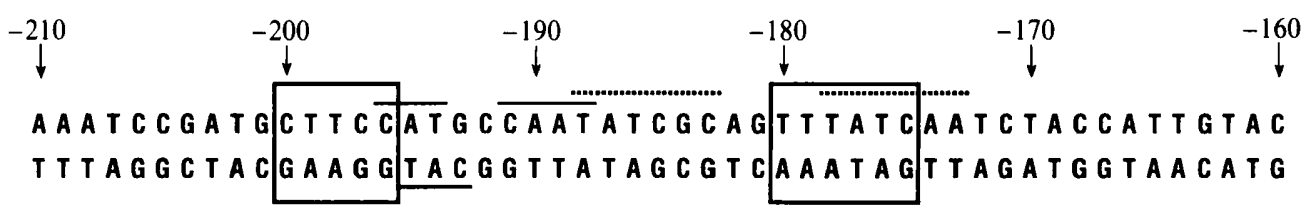

Fig. 3. Putative NIT2 and CYS3 binding sites in the Rhizopus carboxyl proteinase I gene. The DNA sequence at NIT2 binding sites (Fu \& Marzluf, 1990b; Lee et al., 1990) is characterized by the presence of at least two copies of a core sequence, usually present as a tandem repeat, whose consensus is TATCT $60 \% \mathrm{~A}_{45 \%}$. Position five of this core sequence may be occupied by a purine nucleotide (G $20 \%$ or A $20 \%$ ) and position six by a pyrimidine nucleotide (C $35 \%$ or T $20 \%$ ). The core sequence of the putative NIT 2 binding site is marked by broken lines. The CYS3 binding site (Fu \& Marzluf, 1990a) is characterized by usually multiple copies of the sequence CAT (or CAAT) present as at least an inverted repeat separated by usually four or fewer nucleotide bases. Flanking the inverted repeat are homology boxes of five or six nucleotide bases, the entire motif spans at most 26 nucleotide bases. The CAT or CAAT sequences and the homology blocks which define the putative CYS3 binding site, are marked by solid lines and boxes, respectively. Nucleotide bases are numbered with respect to the translation start site and correspond to bases 302-352 in Horiuchi et al. (1988).

derepression of proteinase secretion in the absence of inorganic nitrogen. Ohtsuru et al. (1982a) concluded that $R$. microsporus var. chinensis required exogenous protein as an inducer of proteinase secretion. However, their results do not require this conclusion. The control medium they used contained $\mathrm{NH}_{4} \mathrm{Cl}, \mathrm{MgSO}_{4}$ and glucose. That they did not observe proteinase secretion in this medium is consistent with the results presented here, namely that proteinase secretion is repressed in minimal medium. They obtained proteinase secretion in medium in which protein was the sole source of carbon but did not examine proteinase secretion in carbon-free medium. It remains possible therefore, and consistent with the results presented here, that what they observed was derepression of proteinase secretion in the absence of glucose rather than induction by exogenous protein.

It is postulated that in Neurospora, transcription of the alkaline proteinase gene is regulated by distinct regulatory proteins for each of the nitrogen, sulphur and carbon circuits; the NIT2 protein of the nitrogen circuit (Marzluf, 1981) and presumably the CYS3 protein of the sulphur circuit. A proteinase-specific regulatory gene which mediates induction by exogenous protein is most likely also involved. In $A$. nidulans, proteinase secretion is regulated by the AREA protein of the nitrogen circuit (Arst, 1982) and by separate regulatory proteins for the sulphur and carbon circuits. $R$. oligosporus secretes multiple forms of the carboxyl proteinase (Wang \& Hesseltine, 1970) and $R$. microsporus var. chinensis secretes five isoenzymes of the carboxyl proteinase (Ohtsuru et al., 1982b). It is probable that each form of the enzyme or each isoenzyme is under the control of all three regulatory circuits, since all five isoenzymes are secreted in glucose-free medium (Ohtsuru et al., 1982b), and that for each circuit a distinct regulatory protein is involved.

Analysis of the published sequence for Rhizopus carboxyl proteinase I (Horiuchi et al., 1988) reveals a region which contains all the features of both a NIT2
( -188 to -173$)$ and a CYS3 $(-200$ to -175$)$ binding site (Fig. 3) at the same location as for the most proximal site ( $-0.19 \mathrm{~kb})$ in both Neurospora and Aspergillus genes (Fu \& Marzluf, $1990 a, b$ ). Since the $N$. crassa NIT2 protein can substitute for the AREA protein in A. nidulans (Davis \& Hynes, 1987) it would be interesting to know whether the NIT2 and CYS3 genes are able to substitute for the as yet unidentified regulatory genes in R. oligosporus.

R. oligosporus USDB 0224 was provided by Professor G. Lim, currently Director, National Institute of Education, Nanyang Technological University, Singapore. Pepstatin was a gift from the Sigma Chemical Company, USA. Yvonne Handajani provided excellent technical assistance with some experiments and Peter Stockwell (Dunedin, NZ) helped to obtain computer software. P.C.F. is grateful to the FBUKSW for providing facilities for this work.

\section{References}

ARST, N. A., JR. (1982). A near terminal pericentric inversion leads to nitrogen metabolite derepression in Aspergillus nidulans. Molecular and General Genetics 188, 490-493.

CoHen, B. L. (1973). Regulation of intracellular and extracellular neutral and alkaline proteases in Aspergillus nidulans. Journal of General Microbiology 79, 311-320.

COHEN, B. L. \& DRuCKer, H. (1977). Regulation of exocellular protease in Neurospora crassa: induction and repression under conditions of nitrogen starvation. Archives of Biochemistry and Biophysics 182, 601-613.

COHEN, B. L., Morris, J. E. \& Drucker, H. (1975). Regulation of two extracellular proteases of Neurospora crassa by induction and by carbon-nitrogen and sulfur-metabolite repression. Archives of Biochemistry and Biophysics 169, 324-330.

DAVIS, M. A. \& HYNES, M. J. (1987). Complementation of are $A^{-}$ regulatory gene mutations of Aspergillus nidulans by the heterologous regulatory gene nit-2 of Neurospora crassa. Proceedings of the National Academy of Sciences of the United States of America 84, 3753-3757.

Eggstein, M. \& KreutZ, F. H. (1967). In Techniques in Protein Chemistry, p. 340. Edited by J. L. Bailey. London: Elsevier.

FARLEY, P. C. (1991). Evaluation of the use of glucosamine measurements, for determining Rhizopus oligosporus growth during tempe fermentation. Biomedical Letters 46, 227-228.

Fu, Y. H. \& Marzluf, G. A. (1987). Characterization of nit-2, the major nitrogen regulatory gene of Neurospora crassa. Molecular and Cellular Biology 7, 1691-1696. 
FU, Y. H. \& MARzLUf, G. A. (1990a). cys-3, the positive-acting sulfur regulatory gene of Neurospora crassa, encodes a sequence-specific DNA-binding protein. The Journal of Biological Chemistry 265, 11942-11947.

Fu, Y. H. \& MARzluf, G. A. (1990b). nit-2, the major positive-acting nitrogen regulatory gene of Neurospora crassa, encodes a sequencespecific DNA-binding protein. Proceedings of the National Academy of Sciences of the United States of America 87, 5331-5335.

Horiuchi, H., Yanal, K., Okazaki, T., Takagi, M. \& Yano, K. (1988). Isolation and sequencing of a genomic clone encoding aspartic proteinase of Rhizopus niveus. Journal of Bacteriology 170, 272-278.

JARAI, G. \& MARzluf, G. A. (1991). Sulfate transport in Neurospora crassa: regulation, turnover and cellular localization of the CYS-14 protein. Biochemistry 30, 4768-4773.

Kalisz, H. M., WoOD, D. A. \& Moore, D. (1987). Production, regulation and release of extracellular proteinase activity in Basidiomycete fungi. Transactions of the British Mycological Society 88, 221-227.

LASURE, L. L. (1980). Regulation of extracellular acid protease in Mucor miehei. Mycologia 72, 483-493.

LeAKe, J. R. \& ReAD, D. J. (1990). Proteinase activity in Mycorrhizal fungi II. The effects of mineral and organic nitrogen sources on induction of extracellular proteinase in Hymenoscyphus ericae. New Phytologist 116, 123-128.

LEE, H., FU, Y. H. \& MARzLuF, G. A. (1990). Nucleotide sequence and DNA recognition elements of alc, the structural gene which encodes allantoicase, a purine catabolic enzyme of Neurospora crassa. Biochemistry 29, 8779-8787.

LIM, G., TAN, T. K. \& RAHIM, N. A. (1987). Variations in amylase and protease activities among Rhizopus isolates. MIRCEN Journal 3 , 319-322.

MARZLUF, G. A. (1981). Regulation of nitrogen metabolism and gene expression in fungi. Microbiological Reviews 45, 437-461.

NORTH, M. J. (1982). Comparative biochemistry of the proteinases of eucaryotic microorganisms. Microbiological Reviews 46, 308-340.

Nout, M. J. R. \& Rombouts, F. M. (1990). Recent developments in tempe research. Journal of Applied Bacteriology 69, 609-633.

Ohtsuru, M., TANG, J. \& Delaney R. (1982a). Liquid culture of Rhizopus chinensis for the production of acid protease rhizopupepsin. International Journal of Biochemistry 14, 921-924

Ohtsuru, M., Tang, J. \& Delaney R. (1982b). Purification and characterization of rhizopupepsin isozymes from a liquid culture of Rhizopus chinensis. International Journal of Biochemistry 14, 925-932.

Schindler, J., Lehmann, R., Pfeiffer, H. \& SChmid, R. (1983). Extracellular acid protease of Rhizopus rhizopodiformis. In Enzyme Technology, pp. 69-77. Edited by R. M. Lafferey. Berlin: Springer Verlag.

Shepherd, M. G., Ghazali, H. M. \& Sullivan, P. A. (1980). NAcetyl-D-glucosamine kinase and germ-tube formation in Candida albicans. Experimental Mycology 4, 147-159.

WANG, H. L. \& Hesseltine, C. W. (1965). Studies on the extracellular proteolytic enzymes of Rhizopus oligosporus. Canadian Journal of Microbiology 11, 727-732.

W ANG, H. L. \& Hesseltine, C. W. (1970). Multiple forms of Rhizopus oligosporus protease. Archives of Biochemistry and Biophysics 140, 459-463.

WANG, H. L., Vespa, J. B. \& Hesseltine, C. W. (1974). Acid protease production by fungi used in soybean food fermentations. Applied Microbiology 27, 906-911. 